\title{
Kinerja Investasi Exchange Trade Fund di Indonesia
}

\section{Gayatri $^{1}$ \\ Fakultas Ekonomi dan Bisnis Universitas Udayana, Indonesia}

\author{
Ni Luh Sari Widhiyani ${ }^{2}$ \\ Fakultas Ekonomi dan Bisnis \\ Universitas Udayana, Indonesia
}

Surel : gayatri_akuntansi@unud.ac.id

ABSTRAK

Tujuan yang ingin dicapai dalam penelitian ini untuk mendapatkan bukti empiris tentang pengaruh stock selection skill, market timing ability, fund size dan fund age terhadap kinerja exchange trade fund. Populasi dalam penelitian ini yaitu seluruh produk investasi exchange trade fund yang terdaftar di Bursa Efek Indonesia dari tahun 2017 sampai dengan tahun 2019. Teknik pengambilan sampel menggunakan purposive sampling. Untuk menguji hipotesis digunakan analisis regresi linier berganda. Penelitian ini membuktikan bahwa stock selection skill berpengaruh positif terhadap kinerja exchange trade fund di Indonesia. Sedangkan market timing ability, fund size dan fund age tidak berpengaruh positif terhadap kinerja exchange trade fund di Indonesia. Penyebabnya adalah hanya satu manajer investasi PT. Indo Premier Investment Management yang selalu aktif memperjualbelikan exchange trade fund di Indonesia. Penelitian ini berimplikasi pada semakin aktifnya manajer investasi menawarkan produk exchange trade fund untuk menarik minat investor karena mampu bertahan di masa krisis.

Kata Kunci: Exchange Trade Fund; Investasi.

\section{Exchange Trade Fund Investment Performance in Indonesia}

\section{ABSTRACT}

The aim of this research is to obtain empirical evidence about the effect of stock selection skills, market timing ability, fund size and fund age on the performance of exchange trade funds. The population in this study are all exchange trade fund investment products listed on the Indonesia Stock Exchange from 2017 to 2019. The sampling technique uses purposive sampling. To test the hypothesis, multiple linear regression analysis was used. This study proves that stock selection skills have a positive effect on the performance of exchange trade funds in Indonesia. Meanwhile, market timing ability, fund size and fund age do not have a positive effect on the performance of exchange trade funds in Indonesia. The reason is that only one investment manager PT. Indo Premier Investment Management which is always active in trading exchange trade funds in Indonesia. This research has implications for the more active investment managers in offering exchange trade fund products to attract investors because they are able to survive in times of crisis.

Keywords: $\quad$ Exchange Trade Funds; Investation.

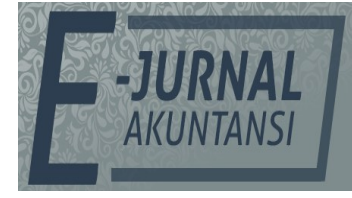

e-ISSN 2302-8556

Vol. 31 No. 7

Denpasar, Juli 2021

Hal. 1632-1643

DOI:

10.24843/EJA.2021.v31.i07.p02

PENGUTIPAN:

Gayatri., \& Widhiyani, N.L.S.

(2021). Kinerja Investasi

Exchange Trade Fund di Indonesia. E-Jurnal Akuntansi, $31(7), 1632-1643$

RIWAYAT ARTIKEL:

Artikel Masuk:

11 Juni 2021

Artikel Diterima:

9 Juli 2021

Artikel dapat diakses : https://ojs.unud.ac.id/index.php/Akuntansi/index 


\section{PENDAHULUAN}

Krisis keuangan global yang terjadi tahun 2002 Bappenas, (2011) disebabkan oleh pemberian subprime mortgage kepada masyarakat berpenghasilan rendah dan tidak tetap di Amerika Serikat. Subprime mortgage memiliki risiko gagal bayar sangat tinggi sehingga lembaga keuangan Lehman Brother mengalami kebangkrutan. Akibat krisis keuangan global, perantara pasar keuangan mencari fitur alternatif dalam menginvestasikan dananya, dan muncullah produk investasi exchange trade funds (ETF).

Investor global menganggap ETF sebagai alternatif produk investasi yang bersifat fleksibel dan transparan karena diperdagangkan di bursa efek layaknya saham. Pada dasarnya ETF merupakan penggabungan karakteristik produk reksadana berbentuk terbuka (open ended fund) dengan saham. ETF di Indonesia sudah diperkenalkan sejak tahun 2007, tetapi baru di tahun 2014 mengalami pertumbuhan yang signifikan sehingga akan menjadi daya tarik bagi investor.

Beberapa pihak yang terlibat dalam ETF terdiri dari: pertama, manajer investasi merupakan pengelola reksadana kontrak investasi kolektif exchange trade fund (KIK ETF); kedua, bank kustodian; ketiga, dealer partisipan merupakan anggota bursa yang menandatangani perjanjian dengan manajer investasi untuk melakukan penjualan atau pembelian unit penyertaan baik untuk kepentingan sendiri maupun untuk kepentingan bersama pemegang unit penyertaan. Dealer partisipan wajib memiliki kemampuan untuk mewujudkan perdagangan yang likuid atas unit penyertaan KIK ETF; keempat, sponsor merupakan pihak yang menandatangani perjanjian dengan manajer investasi untuk melakukan penyertaan dalam bentuk uang dan/atau efek yang untit penyertaannya diperdagangkan di bursa efek, dan kelima, investor. ETF berbentuk kontrak investasi kolektif. Penjualan kembali atau pelunasan unit penyertaan ETF oleh manajer investasi per hari maksimal sebesar 10 persen dari total unit penyertaan. Penjualan atau pelunasan kembali ETF ini hanya dapat dilakukan oleh sponsor dan dealer partisipan (Bursa Efek Indonesia, 2020).

ETF merupakan reksadana terstruktur yang diperdagangkan di pasar modal (Bursa Efek Indonesia, 2020). Reksadana terstruktur merupakan reksadana yang dibeli atau dijual kembali oleh investor pada saat tertentu yang ditentukan oleh manajer investasi. Keuntungan berinvestasi dalam ETF adalah: pertama, unit penyertaan diperdagangkan di Bursa Efek Indonesia; kedua, subcription dan redemption hanya diperbolehkan untuk dealer partisipan dan sponsor; ketiga, gangguan redemption yang dapat mempengaruhi nilai aktiva bersih lebih kecil; keempat, portopolio dalam saham lebih transparan; kelima, trend kenaikan nilai aktiva bersih mengikuti trend kenaikan indeks; keenam, minimum jumlah investasi nasabah jauh lebih kecil. Disisi lain, kelemahan dari ETF adalah: pertama, ETF tetap rawan terhadap fluktuasi harga karena faktor ekonomi makro seperti suku bunga dan nilai tukar; kedua, ETF dapat dipengaruhi oleh stabilitas politik; ketiga, investor tidak dapat memilih saham yang dikelola dalam ETF tetapi hanya berada dalam indeks ETF; keempat, investor tidak dapat menentukan harga yang diinginkan.

Strategi berinvestasi menurut teori portofolio Markowitz untuk menghasilkan return yang maksimal dengan risiko yang minimal dilakukan melalui diversifikasi produk (Markowitz, 2010). Model Markowitz menghasilkan 3 bentuk portofolio yaitu: pertama, maximizing portfolio return terhadap nilai risiko 
pasar dari portofolio yang ditentukan; kedua, minimizing market risk dari portofolio terhadap minimum return yang diharapkan; ketiga, multy criteria optimization yang merupakan kombinasi dari return maksimal dengan risiko minimal dengan pertimbangan porsi dari komponen yang ada ditentukan oleh koefisien investor aversion.

Disisi lain Treynor dan Mazuy Black et al., (1972) membuktikan hubungan antara risiko pasar dan return portofolio tidak selamanya linier. Treynor dan Mazuy menambahkan quadratic term pada market risk premium untuk mengakomodir faktor non linier yang mempengaruhi return portofolio dan dikenal dengan Treynor Measure. Treynor measure mengasumsikan portofolio telah terdiversifikasi dengan baik, sehingga risiko yang relevan hanyalah risiko pasar. Ketika nilai alpha positif menunjukkan adanya stock selection skill dan ketika nilai beta positif menunjukkan adanya market timing ability. Hal ini mengindikasikan manajer investasi menghasilkan excess return portofolio ETF yang lebih besar dibandingkan dengan excess return market.

Penggunaan Teynor Measure didukung oleh penelitian Philippe dan Georges (Cogneau \& Hübner, 2011), hasilnya market timing ability dan stock selection skill manajer investasi menghasilkan kinerja lebih baik jika menggunakan data harian dibandingkan data bulanan dengan menggunakan Sharpe Performance Index (Sharpe, 1994). Penggunaan Sharpe Performance Index digunakan untuk mengevaluasi kinerja ETF yang didasarkan pada risk premium. Risk premium merupakan perbedaan antara rata-rata kinerja yang dihasilkan reksadana dengan rata-rata kinerja investasi bebas risiko (Tandelilin, 2010).

Seorang manajer investasi akan melakukan strategi investasi aktif dalam mengelola portofolionya yaitu dengan melakukan analisis peramalan fundamental perusahaan maupun keadaan pasar di masa depan. Pemilihan saham (stock selection) dan antisipasi waktu (market timing) yang tepat akan mendukung keberhasilan manajer investasi. Tingkat pengembalian ini dilihat dari nilai konstanta. Jika konstanta ETF memiliki nilai positif berarti pembentukan portofolio yang dilakukan oleh manajer investasi optimal atau pembobotan yang telah dilakukan manajer investasi cukup proporsional (Kaslani, 2004). Penelitian Kireina \& Sampurno, (2016), Alexandri, (2015), Putri \& Haryanto, (2014) membuktikan Stock selection skill bernilai positif terhadap kinerja reksadana. Walaupun diteliti dengan metode Jensen Alpha (Panjaitan, 2012), stock selection skill juga berpengaruh positif terhadap kinerja reksadana saham di Indonesia, sehingga hipotesis yang diajukan adalah sebagai berikut.

$\mathrm{H}_{1}$ : Stock selection skill berpengaruh positif terhadap kinerja exchange trade fund di Indonesia.

Market timing ability merupakan kemampuan manajer investasi dalam memprediksi kondisi ekonomi yang ada, apakah baik atau buruk sehingga pengembalian atau return akan memberikan hasil yang optimal. Penelitian Alexandri, (2015) membuktikan market timing ability berpengaruh negatif terhadap kinerja reksadana. Demikian pula penelitian Panjaitan, (2012) membuktikan market timing ability mempunyai pengaruh kecil terhadap kinerja reksadana. Penelitian Kireina \& Sampurno, (2016), Syahid \& Arfianto, (2015) dan Putri \& Haryanto, (2014) membuktikan bahwa market timing ability memiliki pengaruh 
positif dan signifikan terhadap kinerja reksadana. Sehingga hipotesis yang diajukan adalah sebagai berikut.

$\mathrm{H}_{2}$ : Market timing ability berpengaruh positif terhadap kinerja exchange trade fund di Indonesia.

Aktiva sebuah perusahaan mempresentasikan besarnya kekayaan yang dimiliki oleh perusahaan tersebut. Kekayaan perusahaan (Fund size) ditunjukkan oleh skala ekonomi suatu perusahaan. Semakin besar skala ekonomi perusahaan maka semakin besar ukuran perusahaan. Ukuran perusahaan yang besar akan menyebabkan risiko yang dihadapi perusahaan menjadi lebih kecil. Ukuran perusahaan diproksikan dengan total net asset (Hartono, 2017). Penelitian Asriwahyuni, (2017), Pratiwi \& Syaichu, (2011) membuktikan bahwa ukuran perusahaan (fund size) berpengaruh positif signifikan terhadap kinerja reksadana saham. Sehingga hipotesis yang diajukan adalah sebagai berikut.

$\mathrm{H}_{3}$ : Fund size berpengaruh positif terhadap kinerja exchange trade fund di Indonesia.

Umur reksadana (fund age) menunjukkan usia reksadana yang dihitung sejak reksadana tersebut efektif diperdagangkan di bursa efek. Semakin tua umur reksadana, maka kinerja reksadana tersebut semakin baik karena pengalaman dari manajer investasi. Penelitian yang dilakukan oleh Bitomo \& Muharam, (2019), Sukmaningrum \& Mahfud, (2016) dan Mulyawan, (2016) menemukan bahwa fund age berpengaruh positif signifikan terhadap kinerja reksadana. Sehingga hipotesis yang diajukan adalah sebagai berikut.

$\mathrm{H}_{4}$ : Fund age berpengaruh positif terhadap kinerja exchange trade fund di Indonesia.

\section{METODE PENELITIAN}

Tujuan penelitian ini untuk mendapatkan bukti empiris tentang pengaruh stock selection skill, market timing ability, fund size dan fund age terhadap kinerja exchange trade fund di Indonesia. Populasi dalam penelitian ini adalah seluruh produk reksadana yang dipublikasikan di Bursa Efek Indonesia Tahun 2019 sejumlah 38 unit. Teknik pengumpulan data diperoleh melalui studi kepustakaan dengan menggunakan data Bursa Efek Indonesia periode 2016 sampai dengan 2019. Jenis data sekunder yang digunakan adalah pooling data (Gujarati, 2013). Sampel penelitian ini adalah produk investasi reksadana exchange trade fund sejumlah 9 unit. Teknik pengambilan sampel menggunakan purposive sampling dengan tujuan untuk mendapatkan sampel yang representatif sesuai dengan kriteria yang ditentukan yaitu: pertama, exchange trade fund efektif terdaftar di Bursa Efek Indonesia periode 2017-2019; kedua, exchange trade fund masih aktif diperdagangkan sampai dengan tahun 2019; ketiga, exchange trade fund melaporkan nilai aktiva bersih ke Bursa Efek Indonesia periode Desember 2016 sampai dengan Desember 2019; dan keempat, exchange trade fund berdenominasi rupiah. Variabel dependen ( $\mathrm{Y}$ ) dalam penelitian ini adalah kinerja exchange trade fund yang mencerminkan tingkat pengembalian atau return yang diberikan exchange trade fund kepada investor. Kinerja exchange trade fund diukur dengan menggunakan Sharpe's Performance Index. Pengukuran Sharpe's diformulasikan sebagai risk premium terhadap standar deviasi (Sharpe, 1994). Model Sharpe memberikan 
informasi yang lebih baik dalam memperhitungkan risiko sistematik dan risiko tidak sistematik. Pengukuran Sharpe diformulasikan sebagai berikut.

$$
S_{p}=\frac{R_{p}-R_{f}}{\sigma_{p}}
$$

Keterangan:

$$
\begin{array}{ll}
\mathrm{S}_{\mathrm{p}} & =\text { Indeks Kinerja Sharpe } \\
\mathrm{R}_{\mathrm{p}} & =\text { Rata-rata kinerja periode pengukuran } \\
\mathrm{R}_{\mathrm{f}} & =\text { Rata-rata kinerja investasi bebas risiko periode pengukuran } \\
\mathrm{\sigma}_{\mathrm{p}} & =\text { Standar deviasi exchange trade fund periode pengukuran }
\end{array}
$$

Variabel independen dalam penelitian ini terdiri dari pertama, Stock selection skill $\left(X_{1}\right)$ yaitu kemampuan manajer investasi untuk melakukan analisis pemilihan portopolio exchange trade fund terbaik; kedua, Market timing ability $\left(\mathrm{X}_{2}\right)$ merupakan kemampuan dari manajer investasi untuk membeli atau menjual instrumen investasi dengan menggunakan strategi perdagangan mekanis. Model TreynorMazuy (1966) digunakan untuk menghitung stock selection skill dan market timing ability dengan formula sebagai berikut.

$$
R_{d}-R_{f}=\alpha+\beta\left(R_{m}-R_{f}\right)+\gamma\left(R_{m}-R_{f}\right)^{2}+\varepsilon_{p}
$$

Keterangan:

$$
\begin{array}{ll}
\mathrm{R}_{\mathrm{p}} & =\text { Return exchange trade fund pada periode } \mathrm{t} \\
\mathrm{R}_{\mathrm{f}} & =\text { Return bebas risiko pada periode } \mathrm{t} \\
\mathrm{R}_{\mathrm{m}} & =\text { Return pasar pada periode } \mathrm{t} \\
\mathrm{\alpha} & =
\end{array}
$$

Ketiga, Fund size $\left(\mathrm{X}_{3}\right)$, Kekayaan exchange trade fund dapat dinilai dari besarnya total net assets yang dimiliki (Hartono, 2017). Kekayaan yang dimiliki perusahaan umumnya menunjukkan skala ekonomi suatu perusahaan. Semakin besar skala ekonomi perusahaan, berarti semakin besar ukuran perusahaan. Ukuran perusahaan dapat diformulasikan dengan formula sebagai berikut.

Ukuran $=$ Ln $($ Total Nilai Aktiva Bersih $)$

Keempat, Fund age (X4), atau umur investasi mencerminkan pengalaman manajer investasi dalam mengelola exchange trade fund, dengan asumsi semakin tua umur investasi, berarti kinerjanya semakin baik karena manajer investasi menjadi lebih berpengalaman. Umur investasi diformulasikan dengan formula sebagai berikut.

Umur = Periode penelitian - tanggal efektif exchange trade fund..... Untuk menganalisa data digunakan analisis regresi linear berganda dengan formula sebagai berikut.

Keterangan:

$$
\text { Kinerja }_{i t}=\alpha+\beta_{1}\left(\text { SSS }_{i t}\right)+\beta_{2}\left(\text { MTA At }_{i t}\right)+\beta_{3}\left(\text { Size }_{i t}\right)+\beta_{4}\left(\text { Age }_{i t}\right)+\varepsilon_{i t}
$$

$$
\begin{array}{ll}
\text { Kinerja } & =\text { Kinerja exchange trade fund dengan Indeks Sharpe } \\
\text { SSS } & =\text { Stock selection skill } \\
\text { MTA } & =\text { Market timing ability } \\
\text { Size } & =\text { Fund size (ukuran perusahaan) }
\end{array}
$$




\begin{tabular}{|c|c|}
\hline Age & = Fund age (umur perusahaan) \\
\hline a & $=$ Konstanta \\
\hline$\beta_{1-4}$ & = Koefisien regresi \\
\hline $\mathrm{i}$ & $=$ Exchange trade fund ke i (cross section) \\
\hline $\mathrm{t}$ & = Waktu pengamatan (time series) \\
\hline$\varepsilon$ & $=$ Term of error \\
\hline
\end{tabular}

Untuk memilih model regresi yang paling tepat dalam mengolah data panel diantara fixed effect model, common effect model atau random effect model, dapat dilakukan dengan tiga pengujian yaitu uji chow, uji hausman, dan uji lagrange multiplier. Apabila hasil uji spesifikasi menunjukkan probabilitas chi-square lebih dari 0,05 maka model yang digunakan adalah common effect. Tetapi jika probabilitas chi-square kurang dari 0,05 maka model yang digunakan adalah fixed effect. Uji asumsi klasik yang dilakukan yaitu: uji multikoliniaritas dan uji heteroskedastisitas. Tingkat signifikansi yang digunakan adalah 5\%. Pengolahan data dibantu software eviews.

\section{HASIL DAN PEMBAHASAN}

Dari 38 produk exchange trade fund yang dikelola di Indonesia, maka sampel dalam penelitian yang memenuhi syarat sebanyak 9 produk investasi exchange trade fund. Sampel salam penelitian ini diuraikan dalam Tabel 1.

Tabel 1. Sampel Penelitian

\begin{tabular}{|c|c|c|c|c|}
\hline No & Nama ETF & Kode & $\begin{array}{c}\text { Tanggal } \\
\text { Pencatatan }\end{array}$ & Manajer Investasi \\
\hline 1 & $\begin{array}{l}\text { Reksa Dana Premier ETF } \\
\text { LQ45 }\end{array}$ & R-LQ45X & $18-12-2007$ & $\begin{array}{l}\text { PT Indo Premier } \\
\text { Investment Management }\end{array}$ \\
\hline 2 & $\begin{array}{l}\text { Reksa Dana Premier ETF } \\
\text { IDX30 }\end{array}$ & XIIT & $30-10-2012$ & $\begin{array}{l}\text { PT Indo Premier } \\
\text { Investment Management }\end{array}$ \\
\hline 3 & $\begin{array}{l}\text { Reksa Dana Premier ETF } \\
\text { Indonesia Consumer }\end{array}$ & XIIC & 30-04-2013 & $\begin{array}{l}\text { PT Indo Premier } \\
\text { Investment Management }\end{array}$ \\
\hline 4 & $\begin{array}{l}\text { Reksa Dana Syariah } \\
\text { Premier ETF JII }\end{array}$ & XIJI & 30-04-2013 & $\begin{array}{l}\text { PT Indo Premier } \\
\text { Investment Management }\end{array}$ \\
\hline 5 & $\begin{array}{l}\text { Reksa Dana Premier ETF } \\
\text { SMINFRA18 }\end{array}$ & XISI & 06-03-2014 & $\begin{array}{l}\text { PT Indo Premier } \\
\text { Investment Management }\end{array}$ \\
\hline 6 & $\begin{array}{l}\text { Reksa Dana Premier ETF } \\
\text { SRI-KEHATI }\end{array}$ & XISR & 26-09-2014 & $\begin{array}{l}\text { PT Indo Premier } \\
\text { Investment Management }\end{array}$ \\
\hline 7 & $\begin{array}{l}\text { Reksa Dana Premier ETF } \\
\text { Indonesia Financial }\end{array}$ & XIIF & 19-11-2014 & $\begin{array}{l}\text { PT Indo Premier } \\
\text { Investment Management }\end{array}$ \\
\hline 8 & $\begin{array}{l}\text { Reksa Dana Premier ETF } \\
\text { Indonesia Stateowned } \\
\text { Companies }\end{array}$ & XISC & 01-10-2015 & $\begin{array}{l}\text { PT Indo Premier } \\
\text { Investment Management }\end{array}$ \\
\hline 9 & $\begin{array}{l}\text { Reksa Dana Premier ETF } \\
\text { Indonesia Sovereign } \\
\text { Bonds }\end{array}$ & XISB & 02-02-2017 & $\begin{array}{l}\text { PT Indo Premier } \\
\text { Investment Management }\end{array}$ \\
\hline
\end{tabular}


ketentuan, Jika probabilitas $<0,05$ maka model yang tepat adalah fixed effect model. Jika probabilitas > 0,05 maka model yang tepat adalah common effect model. Berdasarkan hasil uji yang dilakukan diperoleh nilai probabilitas $>0,05$, sehingga model regresi yang tepat digunakan adalah common effect model (CEM).

Tabel 2. Uji Chow

\begin{tabular}{llll}
\hline Effects Test & Statistic & d.f. & Prob. \\
\hline Cross-section F & 0,904 & $(8,14)$ & 0,540 \\
Cross-section Chi-square & 11,240 & 8 & 0,188 \\
\hline
\end{tabular}

Sumber: Data Penelitian, 2020

Kedua, Uji hausman digunakan untuk menentukan model analisis data panel yang tepat antara fixed effect model (FEM) atau random effect model (REM). Jika probabilitas < 0,05 maka model yang tepat adalah fixed effect model. Jika probabilitas $>0,05$ maka model yang tepat adalah random effect model. Berdasarkan hasil uji diperoleh nilai probabilitas sebesar 0,497 >0,05, sehingga model regresi yang tepat digunakan adalah random effect model (REM).

Tabel 3. Uji Hausman

\begin{tabular}{llll}
\hline Test Summary & Chi-Sq. Statistic & Chi-Sq. d.f. & Prob. \\
\hline Cross-section random & 3,377 & 4 & 0,497 \\
\hline
\end{tabular}

** WARNING: estimated cross-section random effects variance is zero. Sumber: Data Penelitian, 2020

Uji Lagrange Multiplier, digunakan untuk menentukan model yang tepat antara random effect model (REM) atau common effect model (CEM). Jika nilai breuschpagan $<0,05$ maka model yang tepat adalah random effect model. Jika nilai breuschpagan $>0,05$ maka model yang tepat adalah common effect model. Berdasarkan hasil uji diperoleh nilai breusch-pagan sebesar 0,497>0,05, sehingga model regresi yang tepat digunakan adalah common effect model (CEM).

Tabel 4. Uji Lagrange Multiplier

\begin{tabular}{llll}
\hline & Cross-section & Time & Both \\
\hline Breusch-Pagan & 0,163 & 0,456 & 0,619 \\
& $(0,686)$ & $(0,500)$ & $(0,431)$ \\
Honda & $-0,404$ & $-0,675$ & $-0,763$ \\
& $(0,657)$ & $(0,750)$ & $(0,777)$ \\
King-Wu & $-0,404$ & $-0,675$ & $-0,785$ \\
& $(0,657)$ & $(0,750)$ & $(0,783)$ \\
Standardized Honda & 0,261 & $-0,357$ & $-3,434$ \\
Standardized King-Wu & $(0,397)$ & $(0,639)$ & $(1,000)$ \\
& 0,261 & $-0,357$ & $-3,073$ \\
Gourieroux, et al. & $(0,397)$ & $(0,639)$ & $(0,998)$ \\
& -- & -- & 0,000 \\
& & & $(1,000)$ \\
\hline
\end{tabular}

Sumber: Data Penelitian, 2020

Uji Asumsi klasik regresi data panel pada common effect model dengan pendekatan Ordinary least squared (OLS), pada umumnya hanya meliputi uji multikolinearitas dan heteroskedastisitas. Sedangkan uji normalitas dan autokorelasi tidak perlu dilakukan. Karena uji normalitas bukan syarat Best Linier Unbias Estimator (BLUE) dan masalah auto korelasi hanya terjadi pada data time 
series. Untuk mendeteksi ada tidaknya gejala multikolinearitas dalam model regresi dalam penelitian ini digunakan correlation matrik. Apabila nilai koefisien korelasi antar variabel independen kurang dari 0,80, dapat disimpulkan tidak terdapat masalah multikolinearitas antar variabel independen. Berdasarkan Tabel 5 , diperoleh nilai koefisien korelasi dari masing-masing variabel independen lebih kecil dari 0,80, sehingga model regresi tidak terdapat masalah multikolienaritas.

Tabel 5. Uji Mulikolinieritas

\begin{tabular}{ccccc}
\hline & Stock Selection & Market Timing & Fund Size & Fund Age \\
\hline Stock Selection & 1 & $-0,807$ & 0,317 & $-0,080$ \\
Market Timing & $-0,807$ & 1 & $-0,267$ & 0,199 \\
Fund Size & 0,317 & $-0,267$ & 1 & 0,182 \\
Fund Age & $-0,080$ & 0,199 & 0,182 & 1 \\
\hline
\end{tabular}

Sumber: Data Penelitian, 2020

Uji Heteroskedastisitas, menggunakan uji park. Jika nilai probabilitas dari masing-masing variabel independen $>0,05$ maka dalam model regresi tidak terdapat masalah heteroskedastisitas. Berdasarkan Tabel 6, diperoleh nilai probabilitas masing-masing variabel independen $>0,05$ sehingga model regresi tidak terdapat masalah heteroskedastisitas.

Tabel 6. Uji Heteroskedastisitas

\begin{tabular}{lllll}
\hline Variable & Coefficient & Std. Error & t-Statistic & Prob. \\
\hline C & 12,361 & 8,927 & 1,385 & 0,180 \\
Stock Selection & 4,499 & 4,426 & 1,016 & 0,320 \\
Market Timing & 0,017 & 0,032 & 0,543 & 0,592 \\
Fund Size & $-0,443$ & 0,317 & $-1,395$ & 0,177 \\
Fund Age & 0,079 & 0,169 & 0,468 & 0,644 \\
Root MSE & 2,017 & R-squared & 0,109 \\
Mean dependent var & 0,243 & Adjusted R-squared & $-0,053$ \\
S.D. dependent var & 2,177 & S.E. of regression & 2,234 \\
Akaike info criterion & 4,620 & Sum squared resid & 109,790 \\
Schwarz criterion & 4,850 & Log likelihood & $-57,248$ \\
Hannan-Quinn criter. & 4,682 & F-statistic & 0,673 \\
Durbin-Watson stat & 2,084 & Prob(F-statistic) & 0,618 \\
\hline
\end{tabular}

Sumber: Data Penelitian, 2020

Hasil uji statistik deskriptif dengan metode Treynor-Mazuy nampak dalam Tabel 7. Variabel kinerja exchange trade fund menunjukkan nilai terendah sebesar 19,590 dan nilai tertinggi sebesar 1,670. Nilai rata-rata kinerja exchange trade fund sebesar -3,273 dengan standar deviasi sebesar 5,044. Variabel stock selection skill menunjukkan nilai terendah sebesar -0,160 dan nilai tertinggi sebesar 0,740. Nilai rata-rata sebesar 0,058 dengan standar deviasi sebesar 0,171. Variabel market timing ability menunjukkan nilai terendah sebesar -109,110 dan nilai tertinggi sebesar 20,440. Nilai rata-rata sebesar -2,583 dengan standar deviasi sebesar 23,757. Variabel fund size menunjukkan nilai terendah sebesar 26,030 dan nilai tertinggi sebesar 31,050. Nilai rata-rata sebesar 28,701 dengan standar deviasi sebesar 1,495. 
Variabel fund age menunjukkan nilai terendah sebesar 0 dan nilai tertinggi sebesar 12. Nilai rata-rata sebesar 4,777 dengan standar deviasi sebesar 2,750.

Tabel 7. Uji Statistik Deskriptif

\begin{tabular}{lccccc}
\hline & Kinerja ETF & $\begin{array}{c}\text { Stock } \\
\text { Selection }\end{array}$ & $\begin{array}{c}\text { Market } \\
\text { Timing }\end{array}$ & Fund Size & Fund Age \\
\hline Mean & $-3,273$ & 0,057 & $-2,583$ & 28,701 & 4,777 \\
Median & $-2,120$ & 0,030 & 0,550 & 28,390 & 4,000 \\
Maximum & 1,670 & 0,740 & 20,440 & 31,050 & 12,000 \\
Minimum & $-19,590$ & $-0,160$ & $-109,110$ & 26,030 & 0,000 \\
Std. Dev. & 5,044 & 0,171 & 23,757 & 1,495 & 2,750 \\
Skewness & $-1,760$ & 2,378 & $-3,545$ & 0,059 & 1,027 \\
Kurtosis & 6,182 & 10,572 & 16,414 & 1,671 & 4,105 \\
Jarque-Bera & 25,337 & 89,962 & 259,000 & 2,001 & 6,125 \\
Probability & 0,000 & 0,000 & 0,000 & 0,367 & 0,046 \\
Sum & $-88,390$ & 1,560 & $-69,750$ & 774,930 & 129,000 \\
Sum Sq. Dev. & 661,621 & 0,761 & 14675,37 & 58,150 & 196,667 \\
Observations & 27 & 27 & 27 & 27 & 27 \\
\hline
\end{tabular}

Sumber: Data Penelitian, 2020

Berdasarkan uji chow, uji hausman dan uji lagrange multiplier yang dilakukan, diperoleh hasil bahwa common effect model merupakan model yang tepat digunakan dalam penelitian ini. Berdasarkan Tabel 8, diperoleh persamaan regresi sebagai berikut.

Tabel 8. Uji Regresi Common Effect

\begin{tabular}{lllll}
\hline Variable & Coefficient & Std. Error & t-Statistic & Prob. \\
\hline C & 27,292 & 16,69 & 1,635 & 0,116 \\
Stock Selection & 28,478 & 8,275 & 3,441 & 0,002 \\
Market Timing & 0,103 & 0,060 & 1,712 & 0,101 \\
Fund Size & $-1,160$ & 0,594 & $-1,956$ & 0,064 \\
Fund Age & 0,283 & 0,315 & 0,898 & 0,379 \\
Root MSE & 3,770 & R-squared & 0,420 \\
Mean dependent var & $-3,273$ & Adjusted R-squared & 0,314 \\
S.D. dependent var & 5,044 & S.E. of regression & 4,177 \\
Akaike info criterion & 5,862 & Sum squared resid & 383,794 \\
Schwarz criterion & 6,103 & Log likelihood & $-74,144$ \\
Hannan-Quinn criter. & 5,934 & F-statistic & 3,981 \\
Durbin-Watson stat & 2,368 & Prob(F-statistic) & 0,014 \\
\hline
\end{tabular}

Sumber: Data Penelitian, 2020

Untuk mengukur seberapa jauh kemampuan model dalam menerangkan variasi variabel dependen digunakan koefisien determinasi. Berdasarkan Tabel 9, diketahui bahwa nilai Adjusted $R$-squared sebesar 0,314 yang memiliki arti bahwa 31 persen variasi variabel $Y$ dapat dijelaskan oleh stock selection skill, market timing ability, fund size dan fund age. Sedangkan sisanya sebesar 69 persen dijelaskan oleh variasi variabel lain di luar model.

Tabel 9. Uji Koefisien Determinasi

\begin{tabular}{ll}
\hline$R$-squared & 0,420 \\
Adjusted R-squared & 0,314 \\
\hline Sumber: Data Penelitian, 2020 &
\end{tabular}


Untuk menguji model regresi atas pengaruh seluruh variabel independen yaitu stock selection skill, market timing ability, fund size dan fund age terhadap kinerja exchange trade fund digunakan uji F. Berdasarkan Tabel 10, diperoleh nilai probabilitas sebesar 0,014<0,05. Dapat disimpulkan bahwa model regresi dalam penelitian ini layak digunakan atau secara simultan variabel stock selection skill $\left(\mathrm{X}_{1}\right)$, market timing ability $\left(\mathrm{X}_{2}\right)$, fund size $\left(\mathrm{X}_{3}\right)$ dan fund age $\left(\mathrm{X}_{4}\right)$ berpengaruh pada kinerja exchange trade fund $(\mathrm{Y})$.

Tabel 10. Uji Kelayakan Model (Uji F)

$\begin{array}{lr}\text { F-statistic } & 3,981 \\ \text { Prob(F-statistic) } & 0,014\end{array}$

Sumber: Data Penelitian, 2020

Uji $\mathrm{t}$ dalam Tabel 11, dilakukan untuk mengetahui pengaruh dan signifikansi masing-masing variabel independen yaitu stock selection skill, market timing ability, fund size dan fund age terhadap variabel dependen yaitu kinerja exchange trade fund.

Tabel 11. Uji Hipotesis (Uji t)

\begin{tabular}{lcccc}
\hline Variable & Coefficient & Std. Error & $t$-Statistic & Prob. \\
\hline C & 27,292 & 16,691 & 1,635 & 0,116 \\
Stock Selection & 28,478 & 8,275 & 3,441 & 0,002 \\
Market Timing & 0,103 & 0,060 & 1,712 & 0,101 \\
Fund Size & $-1,160$ & 0,594 & $-1,955$ & 0,064 \\
Fund Age & 0,283 & 0,315 & 0,898 & 0,379 \\
\hline
\end{tabular}

Sumber: Data Penelitian, 2020

Untuk membuktikan hipotesis 1, berdasarkan hasil analisis diperoleh hasil Stock Selection Skill $\left(\mathrm{X}_{1}\right)$ menunjukan nilai koefisien regresi sebesar 28.47811, dengan nilai probabilitas sebesar $0,002<0,05$. Sehingga dapat disimpulkan bahwa Stock Selection Skill berpengaruh positif pada kinerja exchange trade fund di Indonesia (Y). Berarti semakin tinggi kemampuan manajer investasi, maka semakin tinggi kinerja exchange trade fund yang dikelola. Hasil ini mendukung penelitian (Alexandri, 2015), (Putri \& Haryanto, 2014), (Kireina \& Sampurno, 2016) dan Panjaitan, (2012).

Untuk membuktikan hipotesis 2, berdasarkan hasil analisis diperoleh hasil variabel Market Timing Ability $\left(\mathrm{X}_{2}\right)$ menunjukan nilai koefisien regresi sebesar 0,103 dengan nilai probabilitas sebesar 0,101 >0,05, sehingga dapat disimpulkan bahwa Market Timing Ability tidak berpengaruh positif pada kinerja exchange trade fund di Indonesia (Y). Artinya manajer investasi tidak mampu memprediksi kinerja exchange trade fund dalam waktu yang tepat untuk memperoleh return optimal. Hasil ini tidak mendukung penelitian (Kireina \& Sampurno, 2016), (Syahid \& Arfianto, 2015) dan (Putri \& Haryanto, 2014)(Mulyawan, 2016).

Untuk membuktikan hipotesis 3, berdasarkan hasil analisis diperoleh hasil variabel Fund Size $\left(X_{3}\right)$ menunjukan nilai koefisien regresi sebesar -1,160, dengan nilai probabilitas sebesar 0,064>0,05, sehingga dapat disimpulkan bahwa Fund Size tidak berpengaruh positif pada kinerja exchange trade fund di Indonesia (Y). Artinya besarnya kekayaan perusahaan tidak berpengaruh pada kinerja exchange trade fund di Indonesia. Hasil ini tidak mendukung penelitian (Asriwahyuni, 2017), dan (Pratiwi \& Syaichu, 2011). 
Untuk membuktikan hipotesis 4, berdasarkan hasil analisis diperoleh hasil variabel Fund Age $\left(\mathrm{X}_{4}\right)$ menunjukan nilai koefisien regresi sebesar 0,283, dengan nilai probabilitas sebesar 0,379 >0,05, sehingga dapat disimpulkan bahwa Fund Age tidak berpengaruh positif pada kinerja exchange trade fund di Indonesia (Y). Penyebabnya rata-rata umur exchange trade fund di Indonesia adalah 4,7 tahun. Hasil penelitian ini tidak mendukung penelitian (Bitomo \& Muharam, 2019), (Sukmaningrum \& Mahfud, 2016), serta (Mulyawan, 2016).

Beberapa penelitian terdahulu yang dilakukan oleh Asriwahyuni, (2017), Kireina \& Sampurno, (2016), Bitomo \& Muharam, (2019), Sukmaningrum \& Mahfud, (2016), Mulyawan, (2016), Syahid \& Arfianto, (2015), Putri \& Haryanto, (2014), Alexandri, (2015), Panjaitan, (2012), serta Pratiwi \& Syaichu, (2011) menggunakan variabel reksadana campuran dengan banyak manajer investasi. Sedangkan penelitian ini khusus menggunakan exchange trade fund. Dari hasil sampel yang diperoleh dalam penelitian ini, hanya satu manajer investasi yang paling aktif memperjualbelikan exchange trade fund di Indonesia yaitu PT. Indo Premier Investment Management. Tidak adanya variasi dari manajer investasi yang aktif memperdagangkan produk exchange trade fund menjadi penyebab tiga hipotesis dalam penelitian ini tidak terbukti.

\section{SIMPULAN}

Secara keseluruhan Stock Selection Skill, Market Timing Ability, Fund Size dan Fund Age berpengaruh terhadap kinerja exchange trade fund di Indonesia. Secara individual Stock Selection Skill berpengaruh terhadap kinerja exchange trade fund di Indonesia. Tetapi Market Timing Ability, Fund Size dan Fund Age tidak berpengaruh terhadap kinerja exchange trade fund di Indonesia. Ukuran perusahaan tidak mempengaruhi kinerja manajer investasi exchange trade fund karena hanya satu manajer investasi yaitu PT. Indo Premier Investment Management yang paling aktif memperdagangkan produk exchange trade fund Indonesia. Demikian pula rata-rata umur exchange trade fund di Indonesia tergolong pendek, produk ini masih dianggap investasi baru. Kurang aktifnya perdagangan exchange trade fund di Bursa Efek Indonesia menjadi keterbatasan dalam penelitian ini.

\section{REFERENSI}

Alexandri, M. B. (2015). Analysis of Mutual Fund's Performance and Persistence in Indonesia. International Journal of Science and Research, 4(1), 1404-1408. https://www.ijsr.net/archive/v4i1/SUB15364.pdf

Asriwahyuni, I. G. A. P. (2017). Pengaruh Ukuran dan Umur Perusahaan pada Kinerja Reksadana Saham di Indonesia. E-Jurnal Akuntansi, 21(2), 1460-1487. https:// doi.org/EJA.2017.v21.i02.p22

Bappenas. (2011). Krisis Keuangan Eropa: Dampak terhadap Perekonomian Indonesia. Tinjauan Ekonomi Triwulan IV. https://www.bappenas.go.id/id

Bitomo, H., \& Muharam, H. (2019). Analisis Faktor-Faktor Yan Mempengaruhi Kinerja Reksa Dana Di Indonesia (Studi Empiris Pada Reksa Dana Konvensional di Indonesia Periode 2012-2014). Diponegoro Journal of Management, 5(2), 133-146. https:// ejournal3.undip.ac.id/index.php/djom/article/view/13849

Black, F., Jensen, M. C., \& Scholes, M. (1972). The Capital Asset Pricing Model: Some 
Empirical Tests. Studies in the Theory of Capital Markets, edited by M. C. Jensen. New York: Praeger.

Bursa Efek Indonesia. (2020). Exchange Traded Fund (ETF). https://www.idx.co.id/produk/exchange-traded-fund-etf/

Cogneau, P., \& Hübner, G. (2011). The 101 Ways to Measure Portfolio Performance. SSRN Electronic Journal, 1-40. https:// doi.org/10.2139/ssrn.1326076

Gujarati, D. N. (2013). Ekonometrika Dasar Buku 2. New York: The McGraw-Hill Companies, Inc.

Hartono, J. (2017). Teori Portopolio dan Analisis Investasi. Edisi 10. BPFE, Yogyakarta. Kireina, I. T., \& Sampurno, R. D. (2016). Analisis Pengaruh Stock Selection Skill Dan Market Timing Ability Dengan Metode Treynor-Mazuy Dan Henriksson-Merton Terhadap Kinerja Reksa Dana Saham (Studi Pada Reksa Dana Saham Tahun 2010-2014). Diponegoro Journal of Management, 5(2), 28-37. https:// ejournal3.undip.ac.id/index.php/djom/article/view/13840

Markowitz, H. M. (2010). Portfolio Theory: As I Still See It. Annual Review of Financial Economics, 2, 1-23. https://doi.org/10.1146/annurev-financial011110-134602

Mulyawan, S. (2016). Kinerja Reksa Dana Saham Syariah Dan Beberapa Faktor Yang Memengaruhinya: Studi Di Pasar Modal Indonesia 2010-2013. Jurnal Wacana Hukum Islam Dan Kemanusiaan, 16(2). https:// doi.org/10.18326/ijtihad.v16i2.217-236

Panjaitan, M. V. (2012). Analisis Kemampuan Stock Selection Dan Market Timing Manajer Investasi Pada Reksadana Saham Di Indonesia. Jurnal Ilmiah Mahasiswa Manajemen, 1(2). https://doi.org/10.33508/jumma.v1i2.188

Pratiwi, A. E. W., \& Syaichu, M. (2011). Pengaruh Expense Ratio, Turnover Ratio, Ukuran Reksadana, Dan Cash Flow Terhadap Kinerja Reksadana (Periode Tahun 2005-2007). http://eprints.undip.ac.id/26699/

Putri, C. H. M., \& Haryanto, A. M. (2014). Analisis Pengaruh Market Timing Ability , Stock Selection Skill , Expense Ratio Dan Tingkat Risiko Terhadap Kinerja Reksa Dana Saham (Studi Pada Reksa Dana Saham Jenis KIK Periode 2009-2013). Diponegoro Journal of Management, 3(4), 1-10. https://ejournal3.undip.ac.id/index.php/djom/article/view/12917

Sharpe, W. F. (1994). The Sharpe Ratio. The Journal of Portfolio Management, 21(1), 49-58. https://doi.org/10.3905/jpm.1994.409501

Sukmaningrum, G., \& Mahfud, M. K. (2016). Analisis Pengaruh Fund Cash Flow, Fund Size, Fund Longevity, Expense Ratio Dan Turnover Ratio Terhadap Kinerja Reksa Dana (Studi Kasus: Reksa Dana Pendapatan Tetap Periode Tahun 2011-2015). Diponegoro Journal of Management, 5(3), 829-839. https://ejournal3.undip.ac.id/index.php/djom/article/view/14672

Syahid, N., \& Arfianto, E. D. (2015). Pengaruh Stock Selection Skill, Market Timing Ability, Fund Longitivity, Fund Cash Flow dan Fund Size terhadap Reksadana (Studi Kasus: Reksadana Saham Periode 2010-2014). Diponegoro Journal of Management, 4(4), 1-11. https:// ejournal3.undip.ac.id/index.php/djom/article/view/13402

Tandelilin, E. (2010). Pasar Modal: Manajemen Portopolio dan Investasi. PT. Kanisius, Yogyakarta. 